\title{
EVALUASI PENGGUNAAN OBAT ASAM URAT DAN POLA PERESEPANNYA PADA PASIEN GOUT ARTRITIS DI INSTALASI RAWAT INAP DI RSUD DELI SERDANG LUBUK PAKAM TAHUN 2020
}

\author{
Asvia Rahayu ${ }^{1}$, Romauli Anna Teresia Marbun², Dian Nopita Sari \\ Manalu ${ }^{3}$, Sa'adah Siregar ${ }^{4}$, Vincentia Ade Rizky ${ }^{5}$, Visensius Krisdianilo ${ }^{6}$ \\ Fakultas Farmasi, \\ Institut Kesehatan Medistra Lubuk Pakam \\ asviarahayu@gmail.com \\ DOI $10.35451 / \mathrm{jfm} . v 3 i 2.681$
}

\begin{abstract}
Uric acid is a disease that arises due to excess purine in the body caused by uric crystals in the joint tissue that attacks the fingers, elbows, knees, toes, toes and heels. Gouty arthritis is a progressive disease caused by deposition of monosodium urate crystals (MSU) found in the joints, kidneys, and other connective tissue due to chronic hyperuricemia. The incidence of gouty arthritis is common in men as many as 25 patients (65.8\%) and women as many as 13 patients (34.2\%). The incidence of gouty arthritis continues to increase with age, at the age of $21-35$ years ( $7.9 \%)$, ages $36-55$ years (36.7\%), age $56-65$ years $(28.9 \%)$, and at the age of $66-75$ years (26.3\%). The purpose of this study was to examine the use of uric acid and its prescription patterns in arthritis patients in Deli Serdang Lubuk Pakam Hospital in 2020 in terms of the right parameters according to the indications, the right patients, the right drugs, and the right dosages. This research is a non-experimental study, data retrospective retrieval was done by looking at the medical record data of arthritis gout patients and analyzed descriptively. Sampling as many as 38 patients with puposive sampling method. Inclusion criteria in this study were patients who were diagnosed with gout and given arthritis medication with complete medical record data. The results of the study evaluated the use of gout and its prescribing patterns in 38 patients at Deli Serdang Lubuk Pakam Regional Hospital in 2020, which were $100 \%$ correct, $100 \%$ right, $100 \%$ right, and $96 \%$ right.
\end{abstract}

Keywords: Gout Artritis, Obat Asam Urat, Peresepan Obat, Sendi, Inflamasi 


\section{Pendahuluan}

Penyakit asam urat merupakan salah satu penyakit dengan kejadian yang cukup tinggi di Indonesia. Peningkatan asam urat disebabkan oleh karena adanya tumpukan kristal urat pada jaringan, terutama pada jaringan sendi, selain itu asam urat juga sering dikaitkan degan gangguan metabolisme purin. Hal ini menyebabkan peningkatan kadar asam urat dalam darah atau yang biasa disebut dengan hiperurisemia. Kadar asam urat dalam darah lebih dari 7,5 mg/dl (Wijayanti, 2017).

Peningkatan kadar asam urat yang terus menerus dapat menyebabkan gout artritis. Gout artritis merupakan salah satu efek yang ditimbulkan akibat adanya pengendapan kristal monosodium urat (MSU) pada suatu jaringan sehingga menyebabkan terjadinya peradangan.

Penyakit gout ditandai dengan rasa sakit dan nyeri pada daerah persendian, ini merupakan bentuk artritis (peradangan sendi) yang umumnya menyerang persendian pada jari, lutut. Kadar asam urat normal pada laki-laki 3,4-7,0 mg/dl, pada wanita 2,4-6,0 $\mathrm{mg} / \mathrm{dl}$, dan anak-anak 2,8-4,0 mg/dl (Lingga, 2012).

Berdasarkan data World Health Organization (WHO) tahun 2017, prevalensi asam urat di dunia sebanyak $34,2 \%$. Asam urat sering terjadi di negara maju seperti Amerika. Prevalensi asam urat di beberapa negara seperti Amerika Serikat mencapai $26,3 \%$ dari keseluruhan total penduduk. Menurut (WHO) tahun 2013, prevalensi untuk penyakit asam urat di USA terdapat $13,6 / 1000$ pria dan $6,4 / 1000$ wanita. Peningkatan kejadian asam urat tidak hanya terjadi di negara maju saja. Namun, peningkatan juga terjadi di negara berkembang, salah satunya di negara Indonesia (Kumar \& Lenert, 2016).
Indonesia merupakan Negara terbesar ke 4 di dunia yang penduduknya menderita asam urat, prevalensi penyakit asam urat di Indonesia sebesar $81 \%$. Adapun berdasarkan Hasil Riset Kesehatan Dasar (Riskesdas) terdapat 3 provinsi diIndonesia yang memiliki prevalensi yang tinggi untuk kejadian penyakit asam urat yaitu Nusa Tenggara Timur $33,1 \%$, Jawa Barat $32,1 \%$ dan Bali 30\%(Riskesdas, 2013).

Berdasarkan hasil Kemenkes (2013) menyatakan kejadian asam urat yang terdiagnosis sebesar $11,9 \%$ dan kejadian tanpa gejala sebesar $24,7 \%$. Penyakit asam urat diperkirakan terjadi pada 840 orang dari setiap 100.000 orang. Penyakit asam urat cenderung terjadi pada rentang usia 35-44 tahun sebesar $37,2 \%$ dan pada usia 45-54 tahun sebesar $45 \%$, angka kejadian asam urat pada pria sebesar $24,3 \%$ dan pada wanita $11,7 \%$. Kejadian pada pria lebih besar dikarenakan pria tidak memiliki hormon estrogen didalam tubuhnya sehingga tidak dapat membantu proses pembuangan asam urat dengan baik, sedangkan pada perempuan dikarenakan adanya hormon estrogen sehingga proses metabolisme purin dapat diseresi melalui urine. (Angelina \& Wirawanni, 2014). Menurut World Health Organization (WHO) tahun 2013 angka kejadian asam urat dengan kasus penderita terdiagnosa hanya $24 \%$ dan $71 \%$ kasus asam urat penderita hanya mengobati dengan cara mengkonsumsi obat-obatan untuk pereda nyeri yang dengan mudah dapat dibeli dengan bebas toko obat. (Tinah, 2011).

Prevalensi kejadian asam urat di Sumatera Utara berdasarkan diagnosis Tenaga Kesehatan adalah $8,4 \%$ dan berdasarkan diagnosis atau gejala $19,2 \%$. 
Berdasarkan survei pendahuluan yang telah dilakukan oleh peneliti di RSUD Deli Serdang Lubuk Pakam Tahun 2020, bahwasanya pada periode Januari 2020 s/d Juni 2020 terdapat 62 data rekam medik yang menderita penyakit asam urat. Hal inilah yang melatar belakangi peneliti untuk melakukan penelitian tentang Evaluasi Penggunaan Obat Asam Urat Dan Pola Peresepannya Pada Pasien Gout Artritis akut dan kronik di Instalasi Rawat Inap di RSUD Deli Serdang Lubuk Pakam Tahun 2020.

\section{Metode}

Penelitian ini menggunakan metode deskriptif, yaitu penelitian yang bertujuan untuk mendapatkan gambaran atau deskripsi tentang suatu keadaan secara objektif, pengambilan data dilakukan secara retrospektif yaitu suatu penelitian yang mengkaji informasi atau mengambil data yang telah lalu dengan menggunakan data sekunder yaitu data yang diperoleh dari sumber kedua (rekam medik) dari tempat penelitian (Benardi, 2015).

Populasi pada penelitian ini adalah semua data rekam medik penderita asam urat pada periode bulan Januari 2020 s/d Juni 2020 sebanyak 62 rekam medik dengan jumlah 38 orang di RSUD Deli Serdang Lubuk Pakam Tahun 2020.

Sampel pada penelitian ini merupakan sebagian dari populasi yang telah memenuhi kriteria inklusi. Teknik pengambilan sampel penelitian dilakukan secara acak sederhana ( simple random samping). Dimana sampel yang di ambil harus memenuhi Kriteria inklusi dan dihitung berdasarkan rumus sampel yang diambil minimal slovin. Rumus sampel slovin merupakan salah satu metode yang digunakan untuk menentukan jumlah sampel minimal yang di ambil bila di ketahui jumlah populasinya.

\section{Hasil}

Berdasarkan hasil penelitian terhadap pasien gout artritis diperoleh populasi sebanyak 62 data rekam medik. Dari populasi diambil secara acak sederhana (Simple random sampling) diperoleh sampel sebanyak 38 pasien terdiagnosa gout artritis (akut) sebanyak 8 pasien $(21,1 \%)$ dan hiperurisemia (Kronik) sebanyak 30 pasien $(78,9 \%)$.

\section{DistribusiKarakteristik responden berdasarkan Jenis Kelamin dan Usia \\ 1. Jenis Kelamin}

Berdasarkan penelitian yang dilakukan terhadap Evaluasi Penggunaan Obat Asam Urat Dan Pola Peresepannya Pada Pasien Gout artritis akut dan kronik di Instalasi Rawat Inap di RSUD Deli Serdang.

Tabel 1. Distribusi Frekuensi Berdasarkan Jenis Kelamin

\begin{tabular}{|l|c|c|}
\hline Jenis Kelamin & $\mathrm{F}$ & $\%$ \\
\hline Laki - Iaki & 25 & $65,8 \%$ \\
\hline Perempuan & 13 & $34,2 \%$ \\
\hline
\end{tabular}

\section{Usia Pasien}

Berdasarkan penelitian yang dilakukan terhadap Evaluasi Penggunaan Obat Asam Urat dan Pola Peresepannya Pada Pasien Gout artritis akut dan kronik di Instalasi Rawat Inap di RSUD Deli Serdang.

Tabel 2. Distribusi Frekuensi Berdasarkan Usia

\begin{tabular}{|l|l|l|}
\hline Umur (Th) & \multicolumn{1}{|c|}{$\mathrm{F}$} & \multicolumn{1}{c|}{$\%$} \\
\hline $21-35$ & 3 & 7,9 \\
\hline $36-55$ & 14 & 36,8 \\
\hline $56-65$ & 11 & 28,9 \\
\hline $66-75$ & 10 & 26,3 \\
\hline Total & 38 & 100 \\
\hline
\end{tabular}

\section{Rasionalitas Penggunaan Obat Asam Urat Berdasarkan : \\ 1. Tepat Pasien}

Tepat pasien adalah ketepatan pemilihan obat yang tidak kontraindikasi 
terhadap keadaan pasien, misalnya riwayat

penyakit pasien, bayi, kehamilan, menyusun, dan usia lanjut (Departemen Kesehatan Republik Indonesia, 2018).

\section{Tepat Indikasi}

Tepat indikasi adalah pemberian obat yang sesuai dengan diagnosa dan keluhan yang ada pada pasien. Penegakkan diagnosis pada pasiengout artritis yaitu dilakukannya pemeriksaan laboratorium seperti kadar asam urat, pemeriksaan radiografi pada gout artritis pada gout kronik serta mengalami nyeri pada lebih dari satu sendi yang terkena (Perhimbunan Reumatologi Indonesia, 2018).

Tabel 3. Distribusi Frekuensi Berdasarkan Tepat Indikasi Pemberian Obat

\begin{tabular}{|l|l|l|}
\hline Ketepatan Indikasi & \multicolumn{1}{|c|}{$\mathrm{F}$} & \multicolumn{1}{c|}{$\%$} \\
\hline Tepat Indikasi & 38 & 100 \\
\hline Tidak Tepat Indikasi & 0 & 0 \\
\hline Total & 38 & 100 \\
\hline
\end{tabular}

\section{Tepat Obat}

Evaluasi ketepatan obat dapat dilihat dari parameter tepat obat yang di evaluasi pada pasien yang mendapatkan obat dengan memenuhi kriteria tepat pasien terkena (Perhimbunan Reumatologi Indonesia, 2018).

Tabel 4. Distribusi Frekuensi Jenis Obat Yang digunakan

\begin{tabular}{|l|l|l|}
\hline \multicolumn{1}{|c|}{ Ketepatan Obat } & \multicolumn{1}{c|}{ F } & \multicolumn{1}{c|}{$\%$} \\
\hline Kolkisin & 9 & 23,7 \\
\hline allopurinol & 29 & 76.3 \\
\hline Total & 38 & 100 \\
\hline
\end{tabular}

\section{Tepat Dosis}

Tepat dosis adalah keadaan dimana pemberian obat berdasarkan jumlah dosis, frekuensi dan durasinya tepat, sehingga tidak menimbulkan efek buruk terhadap pemberian obat. Jika pada pemberian salah satu komponen obat tidak tepat maka dinyatakan pemberian tidak tepat dosis.
Tabel 5. Distribusi Frekuensi Berdasarkan Tepat Dosis Pemberian Obat

\begin{tabular}{|l|l|l|}
\hline Ketepatan Indikasi & \multicolumn{1}{|c|}{$\mathrm{F}$} & \multicolumn{1}{c|}{$\%$} \\
\hline Tepat & 37 & 97, \\
\hline Tidak Tepat Dosis & 1 & 2,63 \\
\hline Total & 38 & 100 \\
\hline
\end{tabular}

\section{Pembahasan}

Berdasarkan hasil penelitian penggunaan obat asam urat dan pola peresepannya pada pasien gout artritis akut dan kronik di Instalasi Rawat Inap di RSUD Deli Serdang Lubuk Pakam dari 38 responden terdapat 25 responden laki - laki dan 13 responden perempuan. Menurut fajarina (2011) gout artritis cenderung terjadi pada laki-laki, karena pada laki-laki tidak memiliki hormon estrogen, sedangkan perempuan memilki hormon estrogen yang membantu proses sekresi purin melalui urine. Namun presentase kejadian gout artritis pada perempuan lebih rendah dari pada laki-laki karena kadar asam urat pada perempuan meningkat pada saat monopause hal ini terjadi karena penurunan hormon estrogen sesuai dengan hasil penelitian yang telah dilakukan (Ariani, 2016) perempuan akan mengalami peningkatan kadar asa urat pada umur $>50$ tahun. Tidak diketahui data yang menunjukkan bahwa jenis kelamin mempengaruhi angka kejadian asam urat, diketahui bahwa asam urat dapat menyerang setiap orang tanpa melihat jenis kelamin (Purwaningsi, 2011).

Berdasarkan karakteristik pasien usia dan jenis kelamin dapat disimpulkan bahwa pasien gout artritis yang menggunakan obat asam urat lebih banyak terjadi pada usia 36-35 Tahun 14 pasien $(36,8 \%)$, usia 56-65 tahun 11 pasien $(28,9 \%)$, kemudian pada usia 66-75 Tahun 10 pasien $(26,3 \%)$ dan pada usia $21-35$ tahun 3 
pasien $(7,9 \%)$ dan berdasarkan jenis kelamin dapat di simpulkan bahwa pasien gout artritis lebih banyak terjadi pada laki-laki 25 pasien $(65,8 \%)$ dan pada perempuan 13 pasien $(34,2 \%)$. Berdasarkan pola peresepannya obat asam urat yang paling sering diresepkan adalah obat Allopurinol sebanyak 29 pasien (76,3\%), dan Kolkisin sebanyak 9 pasien $(23,7 \%)$, berdasarkan Golongan obat yang digunakan allopurinol yaitu golongan Xanthine oksidase dan Kolkisin yaitu golongan NSAID (Non steroid antiinflamasi drugs) dan berdasarkan bentuk sediaan obat yang digunakan adalah tablet.

\section{Kesimpulan}

Berdasarkan kerasionalan obat asam urat dan pola peresepannya pada pasien gout artritis akut dan kronik di RSUD Deli Serdang Lubuk Pakam Diperoleh hasil penelitian mencakup 4 parameter yaitu : Tepat indikasi $(100 \%)$, tepat pasien $(100 \%)$, tepat obat $(97,4 \%)$, dan tepat dosis sebesar $(97,4 \%)$.

\section{Daftar Pustaka}

(2011). Modul Penggunaan Obat Rasional, Ditjen Bina Kefarmasian dan Alat Kesehatan Departemen Kesehatan, Jakarta

Diantari, E., \& Kusumastuti, A. C. (2013). Pengaruh Asupan Purin Dan Cairan Terhadap Kadar Asam Urat Wanita Usia 50-60 Tahun di Kecamatan Gajah Mungkur, Semarang. Journal Of Nutrition College, Vol 2 (1). Halaman 44-49.

Retrievedfrom:

https://ejournal3.undip.ac.id/index.php Ljnc/article/view/2095

Perhimpunan Reumatologi

Indonesia, (2018). Pedoman Diagnosis

Dan Pengelolaan Gout, Perhimpunan Reumatologi Indonesia, Jakarta.

Sugiyono, (2014). Metode

Penelitian Pendidikan Pendekatan Kuantitatif, Kualitatif Dan R \& D. Bandung : Alfabert.

$$
\text { Sharif, (2012). Asuhan }
$$
keperawatan gerontik. Yogjakarta : Nuha Medika

Siswanto, dkk. (2013). Metodologi Penelitian Kesehatan Dan Kedokteran, Pustaka IImu, Jakarta.

$$
\text { Smith C., Diaz F., Pere L.M, }
$$
(2010). Epidemiologi Of Gout : An update, Best Practice \& Research Clinical Rheumatologi. Vol 24 (6). Hal 811-827. Retrieved

From:https://pubmed.ncbi.nlm.nih.gov L21665128/

Yekti, (2016). Cara Jitu Mengatasi Asam Urat. Yogyakarta : Rapha Publising 